\title{
Union bargaining power, subcontracting and innovation*
}

\author{
Hamid Beladi \\ University of Texas at San Antonio, USA \\ and \\ Arijit Mukherjee \\ Nottingham University Business School, UK, CESifo, Germany, INFER, Germany, and \\ GRU, City University of Hong Kong, Hong Kong
}

Submission: March 2016

Accepted: February 17, 2017

\begin{abstract}
We show that if a firm can subcontract production to an informal sector, an increase in union power may either increase or decrease innovation. An increase in union power makes the firm worse off irrespective of its effect on innovation. However, in contrast to the usual belief, an increase in union power may increase consumer surplus and decrease union utility by affecting innovation, thus suggesting that a union may not want to be too powerful. An increase in union power may create an ambiguous effect on social welfare. Our analysis provides new insights to the relation between union power and innovation.
\end{abstract}

Key Words: Consumer surplus; Innovation; Union; Subcontracting JEL Classification: D42; J51; L12; O31

Correspondence to: Hamid Beladi, Department of Economics, College of Business, University of Texas at San Antonio, San Antonio, TX 78249, email: hamid.beladi@utsa.edu .

\footnotetext{
* We thank an anonymous referee and an Associate Editor of this journal, and Thomas Gresik for helpful comments and suggestions. We also thank Li Hao for comments on an earlier version. The usual disclaimer applies.
} 


\section{Introduction}

The book by Freeman and Medoff (1984) on the impacts of labour unions generated a significant amount of interest to examine the effects of unions on innovation. Looking at the US firms, Connolly et al. (1986), Hirsch and Link (1987), Acs and Audretsch (1987, 1988), and Audretsch and Schulenburg (1990) show that there is a negative influence of unions on innovation. Hirsch (1992) shows that most US studies find a negative relation between union power and innovation. Using COMPUSTAT data, Bronas and Deere (1993) show that there is a significant negative relation between firm-specific unionisation rate and innovation. Using mainly aggregative industry level data, Ulph and Ulph (1989) find a negative relation for the high-tech industries in England, while Addison and Wagner (1994) find a positive but insignificant relation. Menezes-Filho and Van Reenen (2003) show strong negative effects of unions on innovation in North America, while that is generally not the case in the UK. Using the industry-level data from Germany, Schnabel and Wagner (1994) show that there is no statistically significant negative influence of unions on innovation. Addison et al. (2001) also use data from Germany and show that works councils are associated with higher wages but no reduction in innovation. There are other studies showing no significant effects of unions on innovation (Schnabel and Wagner, 1992, focusing on manufacturing industries in West Germany, Machin and Wadhwani, 1991 and Menezes-Filho et al., 1998, focusing on the UK firms and Betcherman, 1991, considering Canadian data).

The theoretical analysis by Grout (1984) shows that an increase in union power creates a negative impact on innovation due to the 'hold-up' problem. However, Ulph and Ulph $(1989,1994$ and 1998) show that whether the hold-up problem remains in an oligopoly with strategic $R \& D$ competition may depend on the type of bargaining. If there is ex-post (short-term) bargaining, which does not involve R\&D investment, an increase in union 
power reduces the $R \& D$ investment if the bargaining is over wages only, i.e., if there is a right-to-manage model of firm-union bargaining. ${ }^{1}$ However, if bargaining occurs on wages and employment, i.e., if there is an efficient bargaining, an increase in union power increases the $R \& D$ investment if the unions are weak and they are relatively risk averse. If there is exante (long-term) bargaining, where bargaining occurs on $R \& D$ investment, wage and employment, an increase in union power increases (decreases) the $R \& D$ investment if a successful innovation increases (decreases) employment. ${ }^{2}$

While the extant theoretical literature provides important insights into the relation between union power and innovation, the result that an increase in union power always reduces innovation under ex-post right-to-manage firm-union bargaining cannot explain the empirically observed ambiguous effects of union power on innovation. By considering only in-house production by the firm, this literature ignores subcontracting or outsourcing of production, which is an important empirical regularity in today's world. ${ }^{3}$ We show in this paper that the possibility of both in-house production and subcontracting can explain the ambiguous effects of union power on innovation under ex-post right-to-manage firm-union bargaining.

It is often found that firms in the South Asian and Latin American countries undertake formal in-house production and subcontract to the informal sector (WTO-ILO, 2009 and Ulyssea, 2010). As per Agenor (1996), 60-70\% of the total manufacturing employment in the developing world is in the informal sector. Evidence on informal

\footnotetext{
${ }^{1}$ In a right-to-manage model, firms and unions bargain over wages and the firms hire workers as per their need. On the other hand, in an efficient bargaining model, firms and unions bargain over wages and employment.

${ }^{2}$ See, Menezes-Filho and Van Reenen (2003) for an excellent survey of this literature.

${ }^{3}$ As per the recent estimate provided jointly by ILO and WTO (WTO-ILO, 2009), the informality increases from $50.1 \%$ in early 1990 s to $52.8 \%$ in late 1990 s and then changes to $52.2 \%$ in early 2000 s in Latin American economies. In Africa, this increases initially from 60.9\% in early 1990s to 63.6\% in late 1990s and then reduces to $55.7 \%$ in early 2000 s. On the other hand, Asia accounts for higher informality and it was $78.3 \%$ in early $1990 \mathrm{~s}$ and drops to $68.5 \%$ in late $1990 \mathrm{~s}$ in Asia. After that, it increases to $78.2 \%$ and goes to the level that was in the early 1990s. Evidences on in-house production and outsourcing to the global economy can be found in Cohen and Young (2006).
} 
production can also be found in Schneider and Enste (2000), Guha-Khasnobis and Kanbur (2006) and Mehrotra and Biggeri (2007), to name a few.

For example, a significant amount of subcontracting to the informal sector by the formal sector producers occurs in India. As per Sahu (2010) and Kotwal et al. (2011), subcontracting activities increased significantly in India after the economic reforms in 1999. Mukim (2011) mentions that informal sector in India produces intermediate goods and processed exports and import substitutes for the formal sector producers. Ramaswamy (1999) analyses subcontracting intensity of Indian manufacturing enterprises between 1970 and early 1990s. Moreno-Monroy et al. (2014) do a more recent study on subcontracting by Indian manufacturing enterprises over 1995-2006. They mention that “ $\ldots$ formal enterprises wishing to reduce labor costs subcontract activities to informal enterprises. By their superior status in terms of size and capital, formal enterprises are able to impose stringent conditions on informal enterprises regarding prices, thus extracting most of the value added. ... formal enterprises can benefit from the 'race-to-the-bottom' in terms of labor costs in the informal sector, as it directly translates into higher profitability from subcontracting.... Formal enterprises pursue $[\ldots]$ minimizing costs so that the price of the subcontracted activity is as low as possible." Using formal sector data from the Annual Survey of Industries (ASI), covering all registered Indian manufacturing establishments for the years 1994-1995, 2000-2001 and 2005-2006, and the National Sample Survey (NSS) for the informal sector, covering all unregistered manufacturing establishments including home-based enterprises with owner as the only worker, they show the link between formal sector subcontracting and informal sector employment. Basole et al. (2014) also consider subcontracting in Indian manufacturing sector and find that "The fact that relatively less endowed firms are more likely to enter into subcontracting relations implies that the subcontracting relation might be characterized by asymmetric bargaining firm between the 
parent and the subcontracted firm." Maiti and Marjit (2009) estimate the relation between formal wage, informal wage, and formal productivity in Indian industry.

Cohen and Young (2006) provide evidence on in-house production and outsourcing to the global economy. As mentioned in Beladi and Mukherjee (2012), "DuPont blends its own internal resources with services from more than ten service providers. GMS, a global manufacturing and service firm, has moved from centralized and internal to globally decentralized with internal and external resources. Nokia purchases a large proportion of key electronic components such as semiconductors and microprocessors

from a global network of suppliers, and at the same time it produces these components in its own manufacturing plants (Nokia Annual Report, 2003). Freescale Semiconductor Inc., NXP Semiconductors and Analog Device Inc. behave as Integrated Device Manufacturers and are also customers of Taiwan Semiconductor Manufacturing Company Ltd, which is a semiconductor dedicated foundry."

Given the widespread evidence of subcontracting or outsourcing of production, we provide a new perspective to the literature on union power and innovation by considering subcontracting as a production strategy of the firm. In a model with a monopolist producer, thus ignoring the effects shown by Ulph and Ulph (1989, 1994 and 1998) in oligopolistic markets, we consider that the firm can produce a product in-house by hiring workers from a labour union and/or can subcontract production to the informal sector. ${ }^{4}$ Considering a rightto-manage ${ }^{5}$ model of labour union with ex-post bargaining (suggesting no bargaining on R\&D investment), we show that an increase in union power may either increase or decrease the firm's incentive for innovation. Hence, in contrast to the extant theoretical literature, we show that subcontracting of production may be responsible for creating a positive relation

\footnotetext{
${ }^{4}$ It is worth mentioning that subcontracting to the informal sector in our analysis may be interpreted alternatively as outsourcing to competitive suppliers in another country with a competitive labour market.

${ }^{5}$ See, Layard et al. (1991) and Connolly et al. (1986) for arguments in favour of the right-to-manage model.
} 
between union power and innovation under ex-post right-to-manage firm-union bargaining. ${ }^{6}$

If the firm produces the product in-house, it faces a labour union but subcontracting to the informal sector allows it to avoid the labour union. However, there are diseconomies of scale in the informal sector. Further, the benefits from the firm's innovation may not spill over to the informal sector. The firm determines the amount of in-house production and subcontracting to balance these effects. If the informal sector does not benefit much from the firm's innovation, the benefit from subcontracting is not significant, and a higher rent extraction by the in-house union following an increase in union power reduces the firm's incentive for innovation. However, if the informal sector benefits significantly from the firm's innovation, subcontracting allows the firm to avoid the in-house unionised wage as well as to get significant benefits from its innovation. Hence, an increase in union power may encourage innovation depending on the market size.

As shown in the following analysis, an increase in union power increases the firm's profit from subcontracting but it reduces its profit from in-house production. Further, an increase in union power increases the profit from subcontracting more under innovation compared to no innovation, irrespective of the market size. However, whether an increase in union power reduces the profit from in-house production more under innovation compared to no innovation depends on the market size. If the market is small (large), the loss of profit is higher (lower) under innovation. Hence, an increase in union power increases the incentive for innovation in a large market. If the market is small, there are opposing effects on the incentive for innovation due to different effects on the in-house profit and the profit from subcontracting. We find that the effect on the in-house profit

\footnotetext{
${ }^{6}$ It is worth mentioning that although we consider a firm-union bargaining in our analysis, our results are valid for an alternative situation where, instead of workers, a final goods producer needs a key intermediate product. In this situation, we need to consider our labour union as a profit maximising intermediate goods supplier with
} 
dominates the effect on the profit from subcontracting, and an increase in union power reduces the incentive for innovation.

Our reason for a positive relation between union power and innovation is different from the existing empirical literature. It is argued in Schnabel and Wagner (1994) that inefficient firm-union bargaining may be responsible for the negative effect of unions on innovation in the US studies, and the results may differ for countries with efficient bargaining. This is because the efficient bargaining helps to maximise the pie, which the firm and union can divide. Addison et al. (2001) argue that a direct association is more likely to be observed between works council and product innovation than between works council and process innovation, since product innovation may allow the works council to extract new rent in the future while process innovation may reduce workforce in the shortrun. However, in our analysis, even if there is a process innovation and no efficient bargaining, subcontracting helps the outsourcing firm to avoid the unionised wage, and the outsourcing firm may benefit from its innovated technology in the presence of a significant knowledge spillover. This benefit from subcontracting may create a positive relation between union power and innovation.

We also show that an increase in union power makes the firm worse off irrespective of its effect on innovation. However, in contrast to the usual belief, an increase in union power may increase consumer surplus and decrease union utility by affecting innovation, thus suggesting that a union may not want to be too powerful. An increase in union power may create an ambiguous effect on social welfare.

There is a literature showing the effects of unions on innovation in general equilibrium growth models. Palokangas (1996) considers a situation where innovation requires only skilled labour, and the union-employer federation bargains for skilled and

market power and the informal sector as a set of firms, which can produce the intermediate product but do not have any market power. 
unskilled wages. In this framework, the paper shows that higher wages for unskilled workers increase innovation. Boone (2000) considers two types of innovation - process innovation, which reduces fixed labour costs, and product innovation, which increases product-quality - and shows that with a labour market imperfection, which raises wage above the shadow price of labour, firms over-invest in process innovation and under-invest in product innovation. Palokangas (2004) considers a model with two-sectors - a high-tech sector with innovation and firm-union bargaining, and a traditional sector with no innovation and no union - and shows that an increase in union power increases innovation. Chu et al. (2016) show that an increase in union power creates a positive effect on innovation under an employment-oriented union, a negative effect on innovation under a wage-oriented union, and a neutral effect on innovation if the union is neither wage nor employment oriented. Unlike this literature, we show the effects of strategic subcontracting on the relation between union power and innovation.

Our paper can also be related to a recently growing literature where bi-sourcing, suggesting that a firm produces inputs in-house and sources them from outside suppliers, ${ }^{7}$ may occur due to input market imperfections (Beladi and Mukherjee, 2012 and Stenbacka and Tombak, 2012). ${ }^{8}$ There is another literature suggesting that the presence of powerful unions may encourage firms to locate their plants in countries with no or weak unions (Lommerud et al., 2003 and Mukherjee and Suetrong, 2012). However, unlike our paper, those literatures do not consider how bi-sourcing, which is affected by the in-house input supplier's bargaining power, affects innovation and welfare.

\footnotetext{
${ }^{7}$ As an empirical evidence of bi-sourcing, Nickerson and Silverman (2003) document that 35\% of interstate carriers in the USA trucking industry source drivers in-house as well as from external suppliers. The empirical work by Bas and Carluccio (2009) show that French multinationals design their organisational structures depending on the bargaining power of the firms and trade unions or other input suppliers.

${ }^{8}$ Some other reasons for bi-sourcing are uncertainty in the final goods market (Emons, 1996), moral hazard problems (Du et al., 2006, 2009), capacity utilization problem and deadhead loss (He and Nickerson, 2006), and internal and external scale constraints and the synergic benefits from different procurement modes (Puranam et al., 2013).
} 
The remainder of the paper is organised as follows. Section 2 describes the benchmark model with no subcontracting and shows the effects of an increase in union power. Section 3 extends the model with subcontracting and derives the results. Section 4 concludes.

\section{The benchmark model with no subcontracting}

Assume that there is a monopolist producer, called firm $M$, producing a product that requires only labour. If firm $M$ produces $q$ units of output, it requires $q$ units of labour. We assume that firm $M$ can invest an amount $F$ in $\mathrm{R} \& \mathrm{D}$ to reduce the labour coefficient. If firm $M$ undertakes $\mathrm{R} \& \mathrm{D}$, it can produce $q$ units of output by using $\lambda q$ units of labour, where $\lambda \in(0,1) .{ }^{9}$ We consider in this section that subcontracting is not an option to firm $M$.

There is a labour union that bargains with firm $M$ to determine wage, $w$, and $d$ is the workers' reservation wages. Demand for the product comes from consumers and the inverse market demand function is $P=a-Q$, where $P$ is price and $Q$ is the total output. Like other partial equilibrium analysis, there is no income effect in our analysis.

We consider the following game. At stage 1 , firm $M$ decides whether to invest in R\&D. At stage 2, the labour union and firm $M$ bargain for the unionised wage, $w$. At stage 3, firm $M$ determines output and the profits are realised. We solve the game through backward induction.

We assume in this section that $a>d$, which will ensure that firm $M$ 's equilibrium outputs are positive and the equilibrium wage is not lower than the competitive wage, irrespective of firm $M$ 's R\&D decision.

If firm $M$ invests in $\mathrm{R} \& \mathrm{D}$ in stage 1 , it maximises the following expression to determine its output:

\footnotetext{
${ }^{9}$ We will discuss the implications of continuous R\&D investments later.
} 


$$
\underset{Q}{\operatorname{Max}}(a-Q-\lambda w) Q
$$

The equilibrium output is $Q^{*}=\frac{a-\lambda w}{2}$, and it is positive for $(a-\lambda w)>0$, which is assumed to hold. The labour demand faced by the union is $L^{*}=\lambda Q^{*}$.

If firm $M$ innovates in stage $1, Q^{*}>0$ and bargaining between firm $M$ and the labour union is successful, the gross profit ${ }^{10}$ of firm $M$ is $\pi_{m}=\frac{(a-\lambda w)^{2}}{4}$ and utility of the union is $U=(w-d) \lambda Q^{*}$. However, if bargaining between firm $M$ and the labour union breaks down, the profit of firm $M$ is $\overline{\pi_{m}}=0$ and union utility is $\bar{U}=0$, since the output of firm $M$ is 0 . Hence, the unionised wage is determined by maximising the following expression:

$$
\operatorname{Max}_{w}\left[(w-d) \lambda Q^{*}\right]^{\beta}\left[\pi_{m}-\overline{\pi_{m}}\right]^{(1-\beta)},
$$

where $\beta$ (resp. $(1-\beta)$ ) is bargaining power of the labour union (resp. Firm $M$ ). Since the cost of innovation is sunk at the stage of wage bargaining, it does not appear in the objective function (2). Like many previous papers on labour unions (see, e.g., Grout, 1984, Ulph and Ulph, 1989, 1994, Leahy and Montagna, 2000, Mukherjee, 2008, Maiti and Mukherjee, 2013 and Saha et al., 2013), we assume that if an union member is not employed in firm $M$, it earns the reservation wage $d$.

The equilibrium wage can be found as $w^{*}=\left(d+\frac{\beta(a-d \lambda)}{2 \lambda}\right)$. Given $w^{*}$, we get that $Q^{*}=\frac{(2-\beta)(a-d \lambda)}{4}$, and it is positive for $a>d \lambda$, which is assumed to hold.

Inserting $w^{*}$ in the profit function, we get that if firm $M$ innovates in stage 1 , its net profit is $\pi_{m}^{*}-F=\frac{(2-\beta)^{2}(a-d \lambda)^{2}}{16}-F$. However, if firm $M$ does not innovate in stage 1, 
its net profit can be found by considering $\lambda=1$ and $F=0$. Hence, if firm $M$ does not innovate in stage 1 , its net profit is $\pi_{m}^{0}=\frac{(2-\beta)^{2}(a-d)^{2}}{16}$. An increase in union power reduces firm $M$ 's profit under both innovation and no innovation.

Firm $M$ innovates if $F<\pi_{m}^{*}-\pi_{m}^{0}=\frac{d(2-\beta)^{2}(1-\lambda)(2 a-d-d \lambda)}{16} \equiv \bar{F}$, where $\bar{F}$ shows firm $M$ 's maximum willingness to invest in R\&D. A higher (lower) $\bar{F}$ implies that firm $M$ 's maximum willingness to invest in R\&D increases (decreases), implying that firm $M$ 's incentive for innovation increases (decreases). We get that $\frac{\partial \bar{F}}{\partial \beta}=-\frac{d(2-\beta)(1-\lambda)(2 a-d-d \lambda)}{8}<0$, implying that an increase in union power reduces firm $M$ 's incentive for innovation. This is in line with the previous work, such as Grout (1984), where an increase in union power reduces the firm's incentive for innovation by increasing rent extraction by the labour union.

An increase in union power increases the unionised wage and reduces firm $M$ 's profit, irrespective of firm $M$ 's R\&D decision. However, the rise in wage and the reduction in firm $M$ 's profit are more under innovation than no innovation by firm $M$. Thus, an increase in union power reduces firm $M$ 's incentive for innovation.

The equilibrium union utility and the total equilibrium output are $U^{*}=\frac{\beta(2-\beta)(a-d x)^{2}}{8}$ and $Q^{*}=\frac{(2-\beta)(a-d x)}{4}$ respectively, where $x=\lambda(x=1)$ under innovation (no innovation) by firm $M$. An increase in union power increases union utility and reduces the total output and therefore, consumer surplus under both innovation and no innovation, since the consumer surplus in our analysis is $C S=\frac{Q^{2}}{2}$.

${ }^{10}$ The gross profit does not exclude the cost of innovation, $F$. 
We have shown that an increase in union power increases union utility for a given technology but it also reduces the incentive for innovation. Hence, if we internalise the effect of an increase in union power on innovation, an increase in union power may create an ambiguous effect on union utility. On one hand, an increase in union power tends to increase union utility for a given technology by increasing the wage but, on the other hand, if an increase in union power reduces innovation, it tends to reduce the profit and therefore, the rent that can be extracted by the union, which tends to reduce union utility. The net result depends on the relative strengths of these effects. This is shown in Fig. 1.

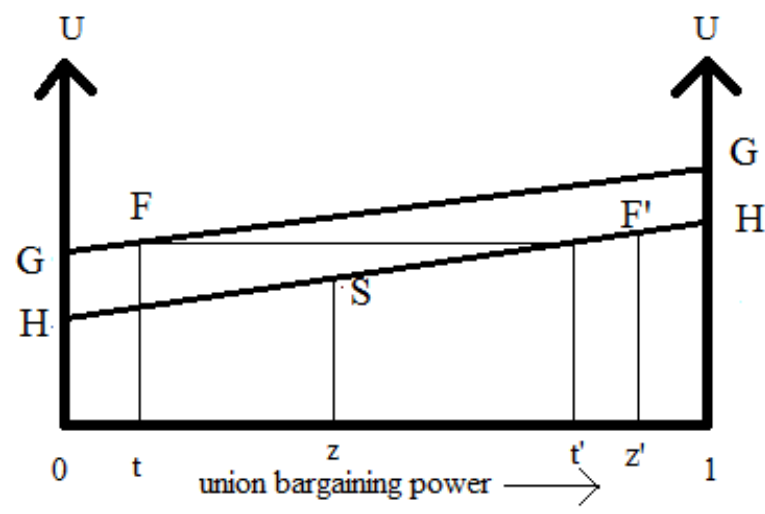

Fig. 1. The effects of an increase in union power on union utility.

The lines $G G$ and $H H$ in Fig. 1 show that, for a given labour coefficient, an increase in union power increases union utility. $H H$ corresponds to the labour coefficient 1 , while $G G$ corresponds to a labour coefficient $\lambda \in(0,1)$, since innovation increases union utility for a given union power. For simplicity, we draw the lines as linear.

Assume that innovation occurs if the union power is $t$, and the corresponding union utility is $F$. If the union power increases from $t$ to, say, $z$, and the higher union power deters innovation, union utility is $S$. Hence, an increase in union power decreases union utility by reducing innovation. However, if the union power increases to $z^{\prime}$, an increase in union power increases union utility even if it reduces innovation. 
The above discussion is summarised in the following proposition.

Proposition 1. If firm $M$ does not have the option to subcontract output to the informal sector, an increase in union power decreases its incentive for innovation, decreases consumer surplus and creates an ambiguous effect on union utility.

\section{The implications of subcontracting}

Now we extend the model of the previous section by incorporating the possibility of subcontracting by firm $M$. Production requires labour and firm $M$ can produce the product either in-house and/or can subcontract production to the informal sector. ${ }^{11} \mathrm{We}$ assume that if firm $M$ produces $q$ units of output in-house, it requires $q$ units of labour, but if firm $M$ subcontracts $q$ units of output to the informal sector, production in the informal sector requires $q^{2}$ units of labour. Hence, the cost of producing through subcontracting is increasing and convex, which can be due to the organisational or monitoring cost related to management and quality control (Shy and Stenbacka, 2005), extra-legal cost and/or search cost (Marjit et al. 2007 and Maiti and Marjit, 2008) ${ }^{12}$. Under subcontracting, firm $M$ needs to contact with each supplier in the informal sector separately, which may create diseconomies of scale.

If firm $M$ invests $F$ amount to undertake R\&D, it can produce $q$ units of output inhouse by using $\lambda q$ units of labour, where $\lambda \in(0,1)$, but if firm $M$ subcontracts $q$ units of

\footnotetext{
11 See Ulyssea (2010) and Maiti and Mukherjee (2013) for recent works where the production process involves both formal and informal sectors.

${ }^{12}$ Hiring informal workers may not be legal and create regulatory problems for the firms. Firms may avoid the problem by offering bribes to the regulators, thus creating an inefficiency. Alternatively, subcontracting to the informal sector may involve additional efforts in searching suitable suppliers, setting acceptable informal terms and conditions, and monitoring them.
} 
output, we assume that production in the informal sector requires $\alpha \lambda q^{2}$ units of labour, where $\alpha \in\left[1, \frac{1}{\lambda}\right]$ inversely measures the degree of knowledge spillover. ${ }^{13}$

It is well known that subcontracting or outsourcing often creates the need for technology transfer from the outsourcing firm to the supplier (UNIDO, 1999). As documented in UNIDO (1999), there are several ways technology transfer can occur under subcontracting. For example:

“- Preparation and supply of technical documents: these include machining drawings, production manuals, quality control and inspection sheets, process flow-charts, quality control flow-charts, list of the required installations, jigs and tools and auxiliary equipment, bills of raw materials and components. In case the contract involves also the production process, the shop floor lay-out, the list of machinery, tools and ancillary services and supplies necessary for the production at the licensee premises are also supplied.

- Technical assistance and training of the subcontractor personnel on the production processes, if the manufacturing cycle is part of the technology transfer. Training schedules and each party share of the related personnel costs are also regulated.

- Machinery and equipment to be procured by the contractor or by the subcontractor, according to the former specifications. If the contractor supplies the production equipment he may also be involved in the production start up."

As discussed in UNIDO (1999), location of the firms may also affect technology transfer under subcontracting; a closer location between the outsourcing firm and its supplier helps to upgrade the subcontractor's technological capabilities. Globalisation is making developing countries as attractive locations for subcontracting and examples of international technology transfer from outsourcing firms to their suppliers can be found in Pack and Saggi (2001). As mentioned in Hobday (1995), firms from industrialized

\footnotetext{
${ }^{13}$ We will discuss the implications of continuous $\mathrm{R} \& \mathrm{D}_{13}$ investments later.
} 
countries often need to transfer their technologies to their suppliers from Asian newly industrialized countries. It is evident from Hou and Gee (1993) that a significant amount of technology transfer occurs from developed-country firms to their suppliers from newly industrialized countries. Evidences of similar technology transfers can also be found in Javorcik (2004) and Blalock and Gertler (2008).

As mentioned in Moreno-Monroy et al. (2014), formal enterprises are “... maximizing the quality of the subcontracted product, so as not to compromise quality standards and ... minimizing the risk of vertically disintegrating the production process, so as to ensure a timely delivery of the final product. Therefore, formal enterprises take into account not only differences in costs between in-house production and subcontracting, but also the productive and technological capacity of potential suppliers (Wattanapruttipaisan [2002]).”

Technology transfer under subcontracting allows the subcontractor to benefit from the innovated technology. We capture the extent of knowledge spillover (or technology transfer) from firm $M$ to the subcontractor by $\alpha \in\left[1, \frac{1}{\lambda}\right]$, where $\alpha=\frac{1}{\lambda}$ implies no knowledge spillover and $\alpha=1$ implies complete technology transfer. Knowledge spillover is incomplete for $\alpha \in\left(1, \frac{1}{\lambda}\right)$.

There is a labour union which bargains with firm $M$ to determine firm $M$ 's in-house wage, $w$, while considering the competitive wage, $d$, as the unionised workers' reservation wages. The competitive wage prevails in the informal sector, thus creating different labour market institutions in the formal and informal sectors. Hence, subcontracting will allow the firm to avoid a higher in-house wage. This is in line with many other papers considering 
subcontracting (see, e.g., Marjit, 2003, Marjit et al. 2007, Maiti and Marjit, 2008, 2009, Maiti and Mukherjee, 2013 and Saha et al., 2014). ${ }^{14}$

We consider the following game. At stage 1, firm $M$ decides whether to invest in R\&D. At stage 2, the labour union and firm $M$ bargain for the unionised wage, $w$. At stage 3, firm $M$ determines the amount of output to be produced in-house and the amount of output to be subcontracted, and the profits are realised. We solve the game through backward induction.

We assume in this section that $a>\left(\frac{1}{\alpha}+d\right)$, which will ensure that firm $M$ 's inhouse production will be positive and the equilibrium unionised wage will not be less than the competitive wage, irrespective of firm M's R\&D decision.

If firm $M$ invests in $\mathrm{R} \& \mathrm{D}$, it maximises the following expression to determine the in-house production, $q$, and the amount of subcontracting, $k$, where $Q=k+q$ :

$$
\underset{q, k}{\operatorname{Max}}(a-q-k-\lambda w) q+(a-q-k) k-\alpha \lambda d k^{2}-F .
$$

The equilibrium in-house production is $q^{*}=\frac{a d \alpha-w-d w \alpha \lambda}{2 d \alpha}$, which creates the in-house labour demand as $L^{*}=\lambda q^{*}$. The in-house production is positive if $($ ad $\alpha-w-d w \alpha \lambda)>0$, which is assumed to hold. The equilibrium amount of subcontracting is $k^{*}=\frac{w}{2 d \alpha}$. A higher in-house wage increases the amount of subcontracting.

Since the marginal cost of informal production is increasing from zero and the marginal cost of in-house production is constant and positive, the amount of subcontracting is determined by the equality of the marginal cost of in-house production, i.e., $\lambda w$, and the marginal cost of informal production, i.e., $2 d k \alpha \lambda$. The total output, i.e.,

\footnotetext{
${ }^{14}$ As already mentioned, in our analysis, outsourcing to competitive suppliers in another country with a competitive labour market may be an alternative interpretation to subcontracting.
} 
$Q=q+k=\frac{a-\lambda w}{2}$, is determined by the equality of the marginal revenue, i.e., $a-2 Q$, and the marginal cost of in-house production, i.e., $\lambda w$.

The equilibrium is shown in Fig. 2. $D D$ and $D M$ show the demand curve and the marginal revenue, and $O A E C$ is the marginal cost. The line $O A$ is the marginal cost of informal production and the line $A E C$ shows the marginal cost of in-house production, which is determined by the firm-union bargaining. The total equilibrium output (i.e., $Q=k+q$ ) is given by the intersection of $D M$ and $O A E C$, where $O k$ is the amount of subcontracting and $k Q$ is the amount of in-house production.

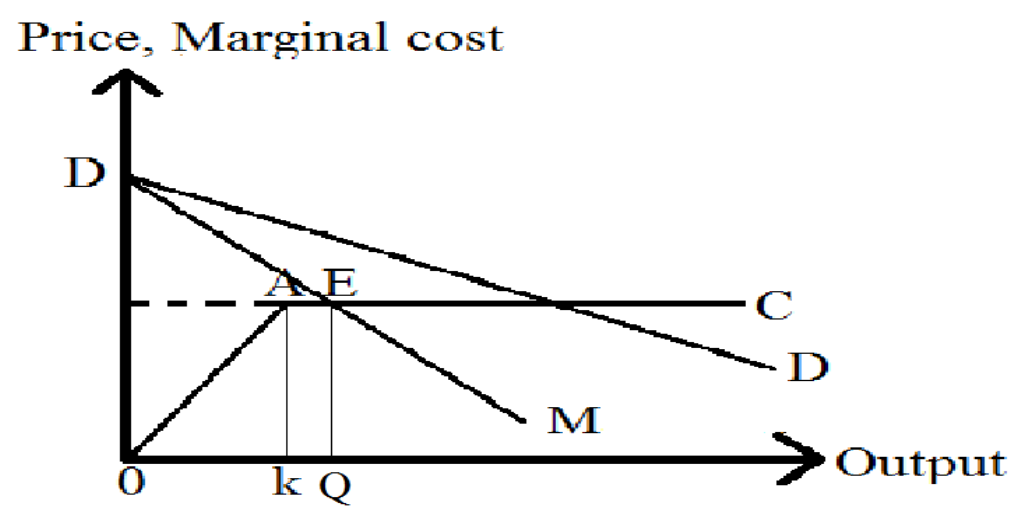

Fig. 2. The equilibrium output.

Given $q^{*}>0$ and $k^{*}>0$, if bargaining between firm $M$ and the labour union is successful, the gross profit of firm $M$ is $\pi_{m}=\frac{a^{2} d \alpha-2 a d w \alpha \lambda+w^{2} \lambda(1+d \alpha \lambda)}{4 d \alpha}$ and union utility is $U=(w-d) \lambda q^{*}$. However, if bargaining between firm $M$ and the labour union breaks down, the gross profit of firm $M$ is $\overline{\pi_{m}}=\frac{a^{2}}{4(1+d \alpha \lambda)},{ }^{15}$ and union utility is $\bar{U}=0$,

\footnotetext{
${ }^{15}$ If bargaining between firm $M$ and the labour union is unsuccessful, firm $M$ subcontracts to maximise $(a-k) k-\alpha \lambda d k^{2}$, which gives $\overline{\pi_{m}}=\frac{a^{2}}{4(1+d \alpha \lambda)}$.
} 
since $q^{*}=0$. Hence, the equilibrium in-house wage is determined by maximising the following expression:

$$
\underset{w}{\operatorname{Max}}\left[(w-d) \lambda q^{*}\right]^{\beta}\left[\pi_{m}-\overline{\pi_{m}}\right]^{(1-\beta)} .
$$

The equilibrium wage can be found as $w^{*}=\frac{d}{2}\left[2+\beta\left(-1+\frac{a \alpha \lambda}{\lambda+d \alpha \lambda^{2}}\right)\right]$. We get that $w^{*}>d$ for $a>\left(\frac{1}{\alpha}+d\right)$, which holds by assumption. We find that an increase in union power (i.e., a higher $\beta$ ) increases the unionised wage, $w^{*}$.

Given $w^{*}$, we get that $q^{*}=\frac{(2-\beta)[a \alpha-(1+d \alpha \lambda)]}{4 \alpha}$, which is positive for $a>\frac{(1+d \alpha \lambda)}{\alpha}$, and the equilibrium amount of subcontracting is $k^{*}=\frac{1}{4}\left(\frac{a \beta}{1+d \alpha \lambda}+\frac{(2-\beta)}{\alpha}\right)$. The total output is $q^{*}+k^{*}=\frac{1}{4}\left(-d(2-\beta) \lambda+a\left(2+\beta\left(-1+\frac{1}{1+d \alpha \lambda}\right)\right)\right)$. An increase in union power increases subcontracting, and decreases in-house production and the total output. Further, the amount of subcontracting increases with more knowledge spillover (i.e., with a lower $\alpha$ ).

Given the equilibrium values of $k, w$ and $q$, we get the equilibrium net profit of firm $M$ under innovation as

$$
\pi^{*}-F=\frac{a^{2} \alpha \lambda\left[4+d \alpha \lambda(2-\beta)^{2}\right]+\mathrm{d}(1+\mathrm{d} \alpha \lambda)(2-\beta)^{2} \lambda[(1+d \alpha \lambda) \lambda-2 a \alpha \lambda]}{16 \alpha \lambda(1+d \alpha \lambda)}-F .
$$

If firm $M$ does not innovate, the equilibrium values can be found by considering $\lambda=1, \alpha=1$ and $F=0$ in (5). Hence, if firm $M$ does not innovate, $q^{*}=\frac{(2-\beta)(a-1-d)}{4}$ and it is positive for $a>(1+d)$, which is assumed to hold. Under no innovation by firm $M$, $k^{*}=\left(\frac{1}{2}+\frac{\beta(a-1-d)}{4(1+d)}\right)$ and the profit of firm $M$ is 


$$
\pi^{0}=\frac{a^{2}\left[4+d(2-\beta)^{2}\right]+d(2-\beta)^{2}(1+d)(1+d-2 a)}{16(1+d)} .
$$

The above discussion gives the following result immediately.

Proposition 2. If $a>\left(\frac{1}{\alpha}+d\right)$, we get $w^{*}>d, k^{*}>0$ and $q^{*}>0$, i.e., firm M's in-house production and subcontracting to the informal sector are positive, irrespective of firm M's R\&D decision.

\subsection{The effects of an increase in union power on innovation}

Firm $M$ innovates if $\pi^{*}-F>\pi^{0}$ or

$$
F<\frac{d}{16}\left[\frac{a^{2}(1-\alpha \lambda)(4-\beta) \beta}{(1+d)(1+d \alpha \lambda)}+2 \mathrm{a}(2-\beta)^{2}(1-\lambda)+\frac{(2-\beta)^{2}\left[\lambda^{2}+\alpha \lambda\left(-1+d\left(-1+\lambda^{2}\right)\right)\right]}{\alpha \lambda}\right] \equiv \bar{F}
$$

$$
\text { We find that } \frac{\partial \bar{F}}{\partial \beta}=\frac{d(2-\beta)}{8}\left(1+\frac{a^{2}(1-\alpha \lambda)}{(1+d)(1+d \alpha \lambda)}-2 a(1-\lambda)-\frac{\lambda^{2}}{\alpha \lambda}+d\left(1-\lambda^{2}\right)\right) \text {, }
$$

which shows the effects of an increase in union power on firm $M$ 's incentive for innovation.

We also find that $\frac{\partial\left(\frac{\partial \bar{F}}{\partial \beta}\right)}{\partial \alpha}<0$, suggesting that as knowledge spillover increases (i.e., $\alpha$ decreases), it increases the rate at which firm $M$ 's incentive for innovation changes with respect to union power.

Proposition 3. Assume $\alpha=1$ (i.e., knowledge spills over completely), and $a>(1+d)$ so that $q^{*}>0$ and $k^{*}>0$. An increase in union power decreases firm M's incentive for innovation (i.e., $\left.\frac{\partial \bar{F}}{\partial \beta}<0\right)$ for $a>\left((1+d),(1+d)(1+d \lambda)+\sqrt{d^{2} \lambda(1+d)(1+d \lambda)}\right)$ but it 
increases firm M's incentive for innovation (i.e., $\frac{\partial \bar{F}}{\partial \beta}>0$ ) for $a>(1+d)(1+d \lambda)+\sqrt{d^{2} \lambda(1+d)(1+d \lambda)}$.

Proof. If $\alpha=1$, we find that $\frac{\partial \bar{F}}{\partial \beta}=\frac{d(2-\beta)(1-\lambda)}{8}\left[1+d+d \lambda+a\left(\frac{a}{(1+d)(1+d \lambda)}-2\right)\right]$, $\frac{\partial \bar{F}}{\partial \beta} \quad$ is $\quad$ convex $\quad$ and $\quad \frac{\partial \bar{F}}{\partial \beta}=0 \quad$ at $\quad a=\left[(1+d)(1+d \lambda)-\sqrt{d^{2} \lambda(1+d)(1+d \lambda)}\right] \quad$ and $a=\left[(1+d)(1+d \lambda)+\sqrt{d^{2} \lambda(1+d)(1+d \lambda)}\right]$, where

$\left[(1+d)(1+d \lambda)-\sqrt{d^{2} \lambda(1+d)(1+d \lambda)}\right]<(1+\mathrm{d})$ Hence, $\quad \frac{\partial \bar{F}}{\partial \beta}<0$ for

$a>\left((1+d),(1+d)(1+d \lambda)+\sqrt{d^{2} \lambda(1+d)(1+d \lambda)}\right.$ but $\frac{\partial \bar{F}}{\partial \beta}>0$ for $a>(1+d)(1+d \lambda)+\sqrt{d^{2} \lambda(1+d)(1+d \lambda)}$.

In the presence of subcontracting, firm $M$ 's profits depend on both in-house production and subcontracting. An increase in union power increases the unionised wage even in the presence of subcontracting but its effect on innovation is different from the one shown in the previous section, where subcontracting is not an option to firm $M$.

If $a>(1+d)$, an increase in union power increases the amount of subcontracting and firm $M$ 's profit from subcontracting (i.e., $\frac{\partial \pi^{\text {OUT }}}{\partial \beta}>0$, where $\left.\pi^{\text {OUT }}=\left[\left(a-q^{*}-k^{*}\right) k^{*}-\lambda d k^{* 2}\right]\right)$. This increase in profit is higher under innovation compared to no innovation (i.e., $\left.\frac{\partial \pi^{\text {OUT }}(\lambda<1)}{\partial \beta}-\frac{\partial \pi^{\text {OUT }}(\lambda=1)}{\partial \beta}>0\right)$. Thus, an increase in union power tends to increase firm $M$ 's incentive for innovation through its effect on the profit from subcontracting. 
Now consider the effect on firm $M$ 's in-house production. If $a>(1+d)$, an increase in union power decreases firm $M$ 's profit from in-house production (i.e., $\frac{\partial \pi^{I H}}{\partial \beta}<0$, where $\left.\pi^{I H}=\left[\left(a-q^{*}-k^{*}-\lambda w\right) q^{*}\right]\right)$. However, the effect of innovation on the loss of in-house profit (i.e., $\frac{\partial \pi^{I H}(\lambda<1)}{\partial \beta}-\frac{\partial \pi^{I H}(\lambda=1)}{\partial \beta}$ ) following an increase in union power is convex with respect to the market size, $a$. If the market is small (i.e., $a \rightarrow(1+d)$ ), the loss of inhouse profit is higher under innovation (i.e., $\left.\frac{\partial \pi^{I H}(\lambda<1)}{\partial \beta}-\frac{\partial \pi^{I H}(\lambda=1)}{\partial \beta}<0\right)$ but if the market is large (i.e., $a>(1+d)(1+d \lambda)+\sqrt{d^{2} \lambda(1+d)(1+d \lambda)}$ ), the loss is lower under innovation (i.e., $\left.\frac{\partial \pi^{I H}(\lambda<1)}{\partial \beta}-\frac{\partial \pi^{I H}(\lambda=1)}{\partial \beta}>0\right)$. Hence, an increase in union power tends to decrease (increase) firm $M$ 's incentive for innovation in a small (large) market through its effect on the in-house profit. The non-monotonic relation occurs due to different effects on the in-house production, $q^{*}$, and the per-unit profit from in-house production, $\left(a-q^{*}-k^{*}-\lambda w\right)$. Innovation (compared to no innovation) reduces in-house production more following an increase in union power, but it creates an ambiguous effect on the reduction of the per-unit in-house profit following an increase in union power, thus creating the non-monotonic effect. The ambiguity on the reduction of the per-unit in-house profit is due to the ambiguous effect on the total output, which is due to the opposing effects on the in-house production and the amount of subcontracting.

Whether an increase in union power increases or decreases firm $M$ 's incentive for innovation depends on its effects on firm $M$ 's profits from in-house production and subcontracting. If the market is large, an increase in union power creates beneficial effects on innovation compared to no innovation through its effects on firm $M$ 's profits from inhouse production and subcontracting. Hence, in a large market, an increase in union power 
increases firm M's incentive for innovation. However, if the market is small, an increase in union power creates opposing effects on innovation compared to no innovation through its effects on firm $M$ 's profits from in-house production and subcontracting. In this situation, the effect on the in-house profit dominates the effect on the profit from subcontracting, and an increase in union power decreases firm $M$ 's incentive for innovation.

Next, consider the case of no knowledge spillover.

Proposition 4. Assume $\alpha=\frac{1}{\lambda}$ (i.e., knowledge does not spill over), and $a>\left(\frac{1}{\alpha}+d\right)$ so that $w^{*}>d, q^{*}>0$ and $k^{*}>0$. An increase in union power decreases firm M's incentive for innovation.

Proof. If $\alpha=\frac{1}{\lambda}$, we find that $\frac{\partial \bar{F}}{\partial \beta}=\frac{-d(2-\beta)(1-\lambda)[(a-1-d)+(a-\lambda-d \lambda)]}{8}<0$, which proves the result.

Proposition 4 contrasts with Proposition 3 and shows that if the benefit from the innovated technology does not spill over to the informal sector, an increase in union power reduces firm $M$ 's incentive for innovation even if it subcontracts to the informal sector. Although an increase in union power increases the amount of subcontracting and firm $M$ 's profit from subcontracting, the gain from subcontracting is not large enough to outweigh firm $M$ 's loss of profit from in-house production because subcontracting induces firm $M$ to sacrifice the benefit from its innovated technology.

Since $\frac{\partial\left(\frac{\partial \bar{F}}{\partial \beta}\right)}{\partial \alpha}<0$ for $\alpha \in\left[1, \frac{1}{\lambda}\right]$, it is immediate from Propositions 3 and 4 that if knowledge spillover is significantly large, an increase in union power increases firm $M$ 's 
incentive for innovation. If we consider $\alpha \in\left[1, \frac{1}{\lambda}\right]$, we get that $\frac{\partial \bar{F}}{\partial \beta}>0$, i.e., an increase in union power increases the incentive for innovation, for $a>\frac{(1+d) \alpha(1-\lambda)(1+d \alpha \lambda)+\sqrt{(1+d) \alpha \lambda(1+d \alpha \lambda)(-1+\alpha(1+d-d \lambda))^{2}}}{\alpha(1-\alpha \lambda)}$. Note that this condition cannot occur for $\alpha=\frac{1}{\lambda}$, thus confirming Proposition 4 . However, if $\alpha=1$, this condition becomes $a>(1+d)(1+d \lambda)+\sqrt{d^{2} \lambda(1+d)(1+d \lambda)}$, as shown in Proposition 3 .

The difference created by subcontracting on the relation between union power and innovation can be explained in the following way. If there is no subcontracting, firm $M$ 's default option is no production if the wage bargaining breaks down. In this situation, an increase in union power decreases firm $M$ 's incentive for innovation by allowing the union to extract a significantly large return from innovation. However, the presence of subcontracting allows firm $M$ to avoid the union power and the benefit from subcontracting increases if firm $M$ 's innovated technology can increase production efficiency in the informal sector. If knowledge spillover about firm $M$ 's innovated technology is significant, the benefit from subcontracting is significantly large to outweigh firm M's in-house profit loss following a rise in union power. In this situation, an increase in union power increases firm $M$ 's incentive for innovation. However, if knowledge spillover is not significant, firm $M$ can avoid the union power by subcontracting but it also needs to sacrifice a large benefit from the innovated technology, and an increase in union power decreases firm $M$ 's incentive for innovation.

\subsection{The effects of an increase in union power on the profit of firm $M$}

The net profits of firm $M$ under innovation and no innovation are shown in (5) and (6) respectively. We get that an increase in union power reduces both $\left(\pi^{*}-F\right)$ and $\pi^{0}$, 
i.e., if firm $M$ either innovates or does not innovate irrespective of the union power, an increase in union power reduces its profit.

If an increase in union power decreases firm $M$ 's innovation, it decreases the profit of firm $M$. This happens since, on one hand, an increase in union power tends to reduce the profit of firm $M$ for a given technology by increasing the unionised wage, and on the other hand, it tends to reduce firm $M$ 's profit by decreasing innovation.

Now consider the situation where an increase in union power increases innovation. Assume that innovation does not occur if the union power is $t$, i.e., $\bar{F}(t)<F$. The profit of firm $M$ in this situation is $\pi^{0}(t)$. If the union power increases from $t$ to, say, $z$, and the higher union power induces innovation, which occurs for $\bar{F}(t)<F<\bar{F}(\mathrm{z})$, the net profit of firm $M$ is $\left(\pi^{*}(\mathrm{z})-F\right)$. Subtracting $\left(\pi^{*}(\mathrm{z})-F\right)$ from $\pi^{0}(t)$ and evaluating this difference at $\bar{F}(t)$, we get that $\left(\pi^{*}(z)-F\right)<\pi^{0}(t)$, suggesting that the net profit of firm $M$ is lower under an increase in union power.

For a given technology, an increase in union power increases the unionised wage and tends to reduce the profit of firm $M$. Even if an increase in union power increases production efficiency by inducing innovation, the wage effect is stronger than the production efficiency effect, thus making firm $M$ worse off under an increase in union power.

The following result summarises the above discussion.

Proposition 5. An increase in union power reduces the profit of firm M, irrespective of its effect on innovation. 


\subsection{The effects of an increase in union power on consumer surplus}

Since consumer surplus in our analysis is $\frac{\left(q^{*}+k^{*}\right)^{2}}{2}$, we look at the effects of an increase in union power on the total output. If an increase in union power does not affect innovation, i.e., if firm $M$ either innovates or does not innovate irrespective of the union power, an increase in union power decreases the total output by increasing the unionised wage, thus reducing consumer surplus. ${ }^{16}$

An increase in union power also reduces consumer surplus if it reduces innovation. On one hand, an increase in union power tends to increase the unionised wage for a given technology, and on the other hand, it reduces production efficiency by reducing innovation. Both the effects reduce the total output and consumer surplus for an increase in union power.

Now consider the case where an increase in union power increases innovation. An increase in union power tends to reduce the total output by increasing the unionised wage for a given labour coefficient. However, if an increase in union power induces innovation, it tends to increase the total output by increasing production efficiency. If the latter effect is stronger than the former, an increase in union power increases the total output and consumer surplus. We show this in Fig. 3.

As discussed above, an increase in union power reduces the total output for a given technology. We also find that, for a given $\beta$, the total output increases with a lower $\lambda$, i.e., $\frac{\partial\left(q^{*}+k^{*}\right)}{\partial \lambda}=\frac{-d}{4}\left((2-\beta)+\frac{a \alpha \beta}{(1+d \alpha \lambda)^{2}}\right)<0$

${ }^{16}$ We get that $\frac{\partial\left(q^{*}+k^{*}\right)}{\partial \beta}=\frac{-d \lambda(a \alpha-1-d \alpha \lambda)}{4(1+d \alpha \lambda)}<0$. 


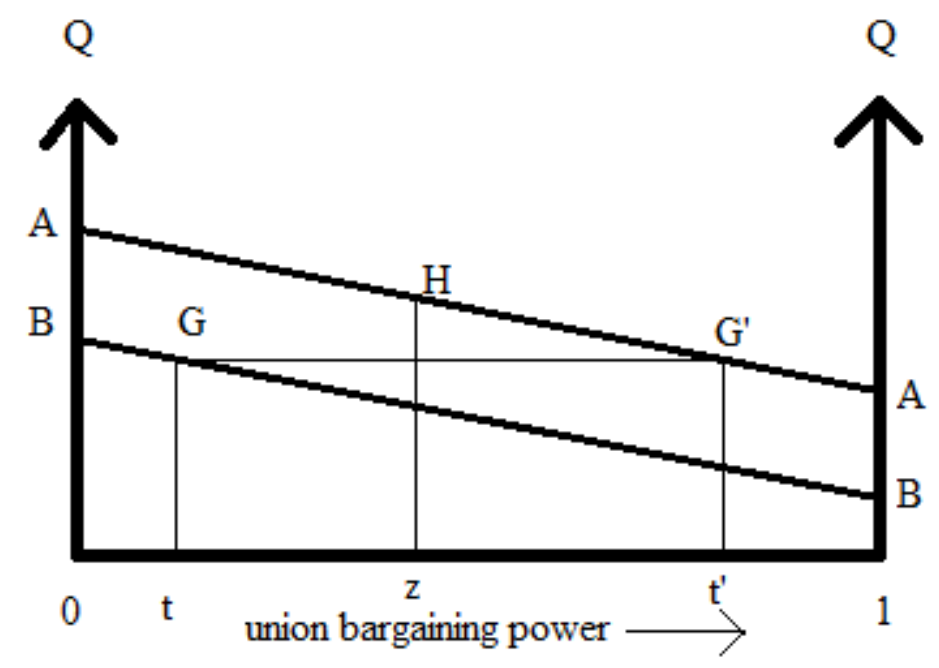

Fig. 3. The effects of an increase in union power on the total output.

The lines $A A$ and $B B$ in Fig. 3 show how an increase in union power affects the total output. $B B$ corresponds to the labour coefficient 1 , while $A A$ corresponds to a labour coefficient $\lambda \in(0,1)$. For simplicity, we draw the lines as linear and consider $\alpha=1$ so that an increase in union power increases the incentive for innovation. Consider a union power $t$. Assume that innovation does not occur if the union power is $t$, which happens for $\bar{F}(t)<F$. The corresponding total output is $G$. If the union power increases from $t$ to, say, $z$, and the higher union power induces innovation, which occurs for $\bar{F}(t)<F<\bar{F}(\mathrm{z})$, the total output is $H$. Hence, an increase in union power increases the total output and consumer surplus by inducing innovation. If the initial union power is $t$ and innovation does not occur at this union power, a union power higher than $t$ increases consumers surplus if the higher union power is less than $t^{\prime}$ and innovation occurs at the higher union power.

The following result is immediate from the above discussion.

Proposition 6. An increase in union power may increase the total output and consumer surplus if it increases innovation. 


\subsection{The effects of an increase in union power on union utility}

Now consider the effects of an increase in union power on union utility. For a given labour coefficient, union utility is $U=\frac{d(2-\beta) \beta \lambda(a \alpha-1-d \alpha \lambda)^{2}}{8 \alpha(1+d \alpha \lambda)}$, which increases with a higher $\beta .{ }^{17}$ Hence, if firm $M$ either innovates or does not innovate irrespective of the union power, an increase in union power increases union utility.

Now we want to show in Fig. 4 that if an increase in union power affects innovation, it may reduce union utility.

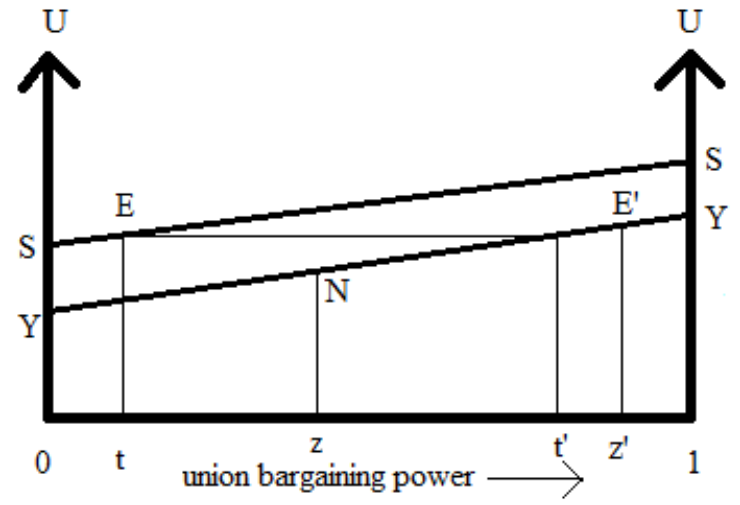

Fig. 4. The effects of an increase in union power on union utility.

The lines $S S$ and $Y Y$ in Fig. 4 show how an increase in union power affects union utility. SS corresponds to the labour coefficient 1 , while $Y Y$ corresponds to a labour coefficient $\lambda \in(0,1)$. For simplicity, we draw the lines as linear and consider $\alpha=1$ so that an increase in union power increases the incentive for innovation. As shown above, for a given labour coefficient, an increase in union power increases union utility, thus making both $S S$ and $Y Y$ positively sloped. However, whether $S S$ will be higher or lower than $Y Y$ is

${ }^{17}$ We have $\frac{\partial U}{\partial \beta}=\frac{d \lambda(1-\beta)(a \alpha-1-d \alpha \lambda)^{2}}{4 \alpha(1+d \alpha \lambda)}>0$. 
not immediate, since $\frac{\partial U}{\partial \lambda}(\alpha=1)=\frac{d(2-\beta) \beta(a-1-d \lambda)[a-(1+d \lambda)(1+2 d \lambda)]}{8(1+d \lambda)^{2}}>(<) 0$ for $a>(1+d \lambda)(1+2 d \lambda)((1+d)<a<(1+d \lambda)(1+2 d \lambda))$. To show our point, we consider $a>(1+d \lambda)(1+2 d \lambda)$ in Figure 4, implying that $\frac{\partial U}{\partial \lambda}>0$, which means that $S S$ is at a higher level than $Y Y$.

Assume that innovation does not occur if the union power is $t$, which occurs for $\bar{F}(t)<F$. The corresponding union utility is $E$. If the union power increases from $t$ to, say, $z$, and the higher union power induces innovation, which occurs for $\bar{F}(t)<F<\bar{F}(z)$, union utility is $N$. Hence, an increase in union power decreases union utility by inducing innovation. However, if the union power increases to $z^{\prime}$ and the higher union power induces innovation, i.e., $\bar{F}(t)<F<\bar{F}\left(z^{\prime}\right)$, an increase in union power increases union utility even if it induces innovation. Thus, it suggests that a marginal increase in the union power that induces innovation reduces union utility, but a discrete increase in the union power may increase union utility even if it induces innovation. However, how much rise in the union power is required to increase union utility when the higher union power induces innovation depends on the reduction in labour coefficient through innovation (i.e., on $\lambda$ ), since a relatively higher (lower) $\lambda$ decreases (increases) the gap between $S S$ and $Y Y$, and the required rise in the union power is less (more).

On one hand, for a given labour coefficient, an increase in union power tends to increase union utility by increasing the unionised wage, although it increases subcontracting. However, if an increase in union power also reduces labour coefficient by inducing innovation, our result suggests that this loss of labour coefficient along with a higher amount of subcontracting may outweigh the effects of the higher unionised wage, thus creating a lower union utility following an increase in union power. 
The following result is immediate from the above discussion.

Proposition 7. An increase in union power may decrease union utility by affecting firm $M$ 's innovation decision.

Like the existing literature, we assumed an exogenously given union power and showed that an increase in union power may reduce union utility. It is then natural to ask whether, given the choice, the union will always prefer an increase in union power. In our framework, the union will certainly prefer to increase its power if the union power does not affect firm $M$ 's R\&D decision, i.e., if firm $M$ either innovates or does not innovate irrespective of the union power. However, the union may prefer a relatively lower power if an increase in union power affects innovation, as shown in Fig. 5.

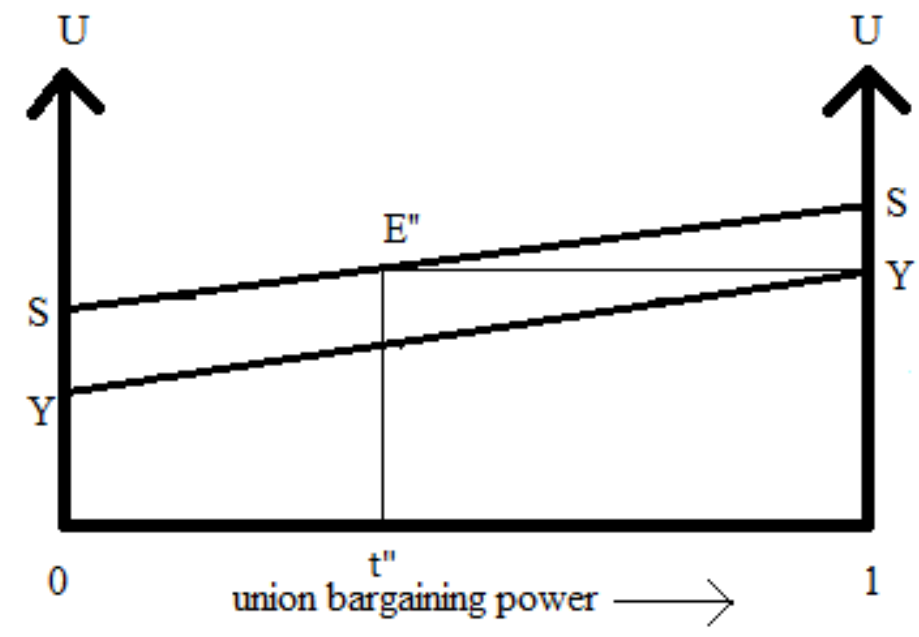

Fig. 5. The incentive for reducing the union power.

Fig. 5, which is like Fig. 4, shows that if an increase in union power induces innovation, the union may prefer a lower union power. Like Fig. 4, we assume in Fig. 5 that $\frac{\partial U}{\partial \lambda}>0$, implying that $S S$, which corresponds to the labour coefficient 1 , is at a higher level 
than $Y Y$, which corresponds to a labour coefficient $\lambda \in(0,1)$. Assume that innovation does not occur if the union power is $t^{\prime \prime}$ but it occurs if the union power is between $t^{\prime \prime}$ and 1 . Following the discussion on Figure 4, it is immediate that if the union power increases from $t^{\prime \prime}$, union utility falls from $E^{\prime \prime}$, which is union utility corresponding to the union power $t^{\prime \prime}$. Hence, the union does not prefer power more than $t^{\prime \prime}$.

Two observations deserve attention at this point. The result that the union may prefer a relatively lower power occurs since the union affects the firm's R\&D decision through its choice of union power. However, if the union cannot commit to its power before the firm's R\&D decision and the union's choice is made at the wage bargaining stage, which is after the firm's R\&D decision, the union will not be able to affect the firm's R\&D decision, and will always prefer to exercise its maximum power. Secondly, even if the union can affect the firm's R\&D decision through its choice of union power, as considered in our analysis, it may always prefer to exercise its maximum power for the reasons not included in our analysis, such as member discontent for not using all its power.

Due to the results in Subsections 3.2, 3.3 and 3.4, it is now immediate that an increase in union power may either increase or decrease social welfare, which is the sum of profit, consumer surplus and union utility.

\subsection{Extensions}

We have considered a framework where firm $M$ decides the amount of in-house production and subcontracting at the same time, and the production through subcontracting is characterised by diseconomies of scale. It may worth noting that the results of this paper hold even if firm $M$ takes a sequential decision on in-house production and subcontracting, and the production through subcontracting is not characterised by diseconomies of scale. We show this in our working paper Beladi and Mukherjee (2015). 
Following Creane and Davidson (2004), Mukherjee (2008) and Maiti and Mukherjee (2013), where firms stagger output decisions among different plants, we consider in Beladi and Mukherjee (2015) that firm $M$ can stagger output decision among inhouse production and subcontracting. More particularly, we consider the game structure where firm $M$ first takes the decision on $\mathrm{R} \& \mathrm{D}$, which is followed by its decision on subcontracting, wage determination by the union and firm M's decision on in-house production. We discuss in our working paper that if firm $M$ decides sequentially on inhouse production and subcontracting, it is beneficial for it to determine the amount of subcontracting before dealing with the in-house labour union and determining the amount of in-house production. If firm $M$ deals with the in-house labour union before subcontracting, it would be able to reduce the union wage up to the effective unit cost of informal production. However, firm $M$ can reduce the union wage below the effective unit cost of informal production by subcontracting production before bargaining with the inhouse labour union.

Considering a linear demand function, we have shown that an increase in union power increases subcontracting, and decreases in-house production and the total output. Further, the amount of subcontracting increases with more knowledge spillover. These effects play important roles in our analysis to create the ambiguous relationship between union power and innovation. We show in Appendix $A$ that the effects of an increase in union power on subcontracting, in-house production and total output shown under a linear demand function remain under a general demand function.

In Proposition 3 and 4, we have considered a binary R\&D process, where firm $M$ either invests or does not invest in R\&D. We show in Appendix $B$ that the qualitative results shown in Propositions 3 and 4 hold even if the R\&D investment is continuous. In this respect, we consider an uncertain $R \& D$, where a higher $R \& D$ investment helps to increase 
the probability of success in $R \& D$, and a deterministic $R \& D$, where a higher $R \& D$ investment helps to reduce the labour coefficient more.

\section{Conclusion}

Although it is empirically observed that an increase in union power creates an ambiguous effect on innovation, the right-to-manage model of labour union could not explain this phenomenon while considering ex-post bargaining, where bargaining does not occur over R\&D investment. We fill this gap in the literature.

Considering a right-to-manage model of labour union and ex-post bargaining, we show that an increase in union power may either increase or decrease a firm's incentive for innovation in the presence of subcontracting, which is an empirically observed phenomenon in today's world. We also show that an increase in union power makes the firm worse off irrespective of its effects on innovation. However, in contrast to the usual belief, an increase in union power may increase consumer surplus and decrease union utility by affecting innovation, thus suggesting that a union may not want to be too powerful. An increase in union power may either increase or decrease social welfare.

We have considered a situation where a firm, when taking the R\&D decision, is internalising the effects of innovation on the unionised wage. In other words, we have assumed that the union can adjust wage following innovation. Although, following the tradition of the literature mentioned in the introduction, we have considered one-time firmunion interaction, our results will hold even if the firm and union interact in multiple periods but the union can adjust wage in every period following innovation. However, there may be situations where it may not be economically viable to adjust wage in every period following innovation. In those periods, the innovating firm takes the R\&D decision based on a pre-negotiated wage. If the union cannot extract more rent by changing the wage 
following innovation, the adverse effects of an increase in union power on innovation are expected to be less compared to the situation where wage can be adjusted after innovation. Hence, an interesting extension of this paper will be to consider a dynamic analysis with multi-period firm-union interactions with multiple innovations where the union can adjust wages in some periods but not in all periods. In this situation, the innovating firm needs to internalise not only the effects of current wage but also the effects of future wages. We leave this issue for future research.

Following the tradition of the literature mentioned in the introduction, we have considered the effects of an increase in union power on a labour-saving or process innovation. However, it is often found that firms invest large amounts on product innovation (Imai, 1992, Mansfield, 1988 and Pavitt et al., 1987). It must be noted that considering product innovation is not a trivial extension of our paper, since the effects of innovation on the labour demand function are different under process and product innovations. While a process innovation reduces labour demand for a given output, a product innovation increases labour demand by increasing the number of products. Hence, a natural extension of this paper would be to see how an increase in union power affects the incentive for product innovation and the market outcomes in the presence of subcontracting. In this respect, the demand function, capturing consumer's preference for more varieties, may play an important role. $^{18}$

Like many other notable contributions (see, e.g., Ulph and Ulph, 1989, 1994 and Menezes-Filho et al., 1998), we have considered a linear demand function - a mostly used demand function in the Industrial Organisation literature - to show that the presence of subcontracting may explain the ambiguous relation between union power and process innovation that is unexplained so far in a right-to-manage model of labour union with ex-

\footnotetext{
${ }^{18}$ See Bowley (1924) and Shubik and Levitan (1980) for demand functions capturing "love for variety" and "no love for variety" respectively.
} 
post bargaining. Our results hold even for those non-linear demand functions which can be approximated as linear functions around the equilibrium values. We have also discussed in Appendix $A$ that the effects of an increase in union power on subcontracting, in-house production and the total output shown under a linear demand function remain under a general demand function. A possible future research would be to analyse the effects of different demand and cost structures on the relation between union power and innovation in the presence of subcontracting. In this respect, one may also want to look at the effects on process and product innovations, and the effects of different preference functions for varieties affecting demand functions.

Finally, we showed that the presence of subcontracting may explain the ambiguous relationship between union power and innovation under a right-to-manage firm-union bargaining. However, if there is an efficient bargaining where the firm and union bargain over wage and employment, the bargaining process tends to reduce distortion due to the union's rent-seeking motive (Schnabel and Wagner, 1994). Hence, it is expected that if the firm-union bargaining is efficient, an increase in union power is likely to increase the possibility of a positive relationship between union power and innovation. Since this issue deserves a detailed analysis, we leave it for future research. 


\section{Appendix A.}

A general demand function. We show in this Appendix that the effects of an increase in union power on subcontracting, in-house production and total output shown under a linear demand function remain under a general demand function.

Assume that the market demand function is $P(q+k)$ with $P^{\prime}<0$, where $q$ is the amount of in-house production and $k$ is the amount of subcontracting. Given R\&D and the unionised wage, firm $M$ maximises the following expression to determine $q$ and $k$ :

$$
\underset{q, k}{\operatorname{Max}}[P(q+k)-\lambda w] q+P(q+k) k-\alpha \lambda d k^{2}-F
$$

The first order conditions of maximisation are:

$$
\begin{aligned}
& P-\lambda w+P^{\prime} q+P^{\prime} k=0 \\
& P^{\prime} q+P+P^{\prime} k-2 \alpha \lambda d k=0 .
\end{aligned}
$$

We assume that the second order conditions hold.

We get the equilibrium values as:

$$
q^{*}=\frac{P-\lambda w}{-P^{\prime}}-\frac{w}{2 \alpha d}, k^{*}=\frac{w}{2 \alpha d} \text { and } q^{*}+k^{*}=\frac{P-\lambda w}{-P^{\prime}} .
$$

We get that $k^{*}>0$ and consider that the parameter values are such that $q^{*}>0$.

It follows from (9)-(11) and the second order conditions of the above maximisation problem that, as $w$ increases, it reduces $q^{*}$ and $\left(q^{*}+k^{*}\right)$, but increases $k^{*}$. Hence, an increase in union power that increases the in-house unionised wage, increases the amount of subcontracting, and reduces in-house production and the total output. Further, it follows from (11) that as the degree of knowledge spillover increases (i.e., $\alpha$ falls), it increases the amount of subcontracting. 


\section{Appendix B.}

Continuous R\&D investment. We considered in the text that firm $M$ either invests in $\mathrm{R} \& \mathrm{D}$ or does not invest in R\&D. Hence, we considered a binary decision on the R\&D investment. We find that an increase in union power increases (decreases) firm $M$ 's incentive for innovation if it increases (decreases) $\bar{F}$ or the difference $\pi^{*}-\pi^{0}$ with respect to union power, $\beta$. It is easy to understand that a similar condition is required even if we consider the following $R \& D$ process with a continuous $R \& D$ investment.

Assume that success in $\mathrm{R} \& \mathrm{D}$ is uncertain and firm $M$ can invest more in $\mathrm{R} \& \mathrm{D}$ to increase the probability of success in R\&D. Assume that the probability of success in R\&D is $p(F)$ with $p^{\prime}(F)>0$ and $p^{\prime \prime}(F)<0$. Hence, firm $M$ determines the amount of R\&D investment, $F$, to maximise its expected profit $E \pi=p(F) \pi^{*}+(1-p(F)) \pi^{0}-F$. The equilibrium $\mathrm{R} \& \mathrm{D}$ investment is determined by $E \pi^{\prime}=0$ or $p^{\prime}(F)\left(\pi^{*}-\pi^{0}\right)-1=0$ with $E \pi^{\prime \prime}<0$. Hence, an increase in union power increases (decreases) the equilibrium R\&D investment if $\frac{\partial\left(\pi^{*}-\pi^{0}\right)}{\partial \beta}>(<) 0$. This is for the following reason. If $\pi^{*}-\pi^{0}$ increases (decreases) with respect to $\beta$, it increases (decreases) the expected marginal profit from $\mathrm{R} \& \mathrm{D}$, which is $p^{\prime}(F)\left(\pi^{*}-\pi^{0}\right)-1$, for a given $\mathrm{R} \& \mathrm{D}$ investment and therefore, encouraging firm $M$ to investment more (less) in R\&D following an increase in union power. ${ }^{19}$

Next, we consider another type of R\&D process with a continuous R\&D investment to show that an increase in union power may increase or decrease the R\&D investment. Assume that success in $\mathrm{R} \& \mathrm{D}$ is certain and a higher investment in $\mathrm{R} \& \mathrm{D}$ allows firm $M$ to achieve a greater reduction in labour coefficient. More specifically, assume that if firm $M$ invests $F$ amount in $\mathrm{R} \& \mathrm{D}$, it incurs a cost $C(F)=\frac{F^{2}}{2}$, but it can reduce the labour 
coefficient from 1 to $(1-F)$ with $(1-F) \geq 0$. With this $R \& D$ process, the equilibrium profit of firm $M$ at stage 1 , i.e., at the $\mathrm{R} \& \mathrm{D}$ stage, is

$$
\begin{gathered}
a^{2} \alpha(1-F)\left[4+d \alpha(1-F)(2-\beta)^{2}\right] \\
\pi^{*}-C(F)=\frac{+\mathrm{d}[1+\mathrm{d} \alpha(1-F)](2-\beta)^{2}(1-F)[\{1+d \alpha(1-F)\}(1-\mathrm{F})-2 a \alpha(1-F)]}{16 \alpha(1-F)[1+d \alpha(1-F)]}-\frac{F^{2}}{2} .
\end{gathered}
$$

The equilibrium R\&D investment is given by:

$$
\frac{d\left(\begin{array}{l}
(2-\beta)\left(\left(-1+2\left(a-d\left(1-F^{*}\right)\right) \alpha\right)\left(-1+d\left(-1+F^{*}\right) \alpha\right)^{2}(2-\beta)+a^{2} \alpha^{2} \beta\right) \\
+a^{2} \alpha^{2}(2) \beta
\end{array}\right)}{16 \alpha\left(-1+d\left(-1+F^{*}\right) \alpha\right)^{2}}-1=0,
$$

where $F^{*}$ is the equilibrium R\&D investment. Assume that the second order condition of maximization is satisfied.

Left hand side (LHS) of (12) shows the marginal profit from R\&D. If LHS of (12) increases with respect to $\beta$, an increase in union power increases (decreases) the marginal profit from $R \& D$ for a given $R \& D$ investment and therefore, encourages (discourages) firm $M$ to invest more in $\mathrm{R} \& \mathrm{D}$.

We get that LHS of (12) increases (decreases) with respect to $\beta$ if

$$
\left(-1+a \alpha-d\left(1-F^{*}\right) \alpha\right)\left(-1+a \alpha-d\left(1-F^{*}\right) \alpha\left(3+2 d\left(1-F^{*}\right) \alpha\right)\right)>(<) 0
$$

Under the assumption of $a>\left(\frac{1}{\alpha}+d\right)$, which ensures $w^{*}>d, q^{*}>0$ and $k^{*}>0$, we get that $\left(-1+a \alpha-d\left(1-F^{*}\right) \alpha\right)>0$. Hence, LHS of (13) is positive (negative) for $\left(-1+a \alpha-d\left(1-F^{*}\right) \alpha\left(3+2 d\left(1-F^{*}\right) \alpha\right)\right)>(<) 0 \quad$ or $\quad a>\frac{1+d \alpha\left(1-F^{*}\right)\left(3+2 d\left(1-F^{*}\right) \alpha\right)}{\alpha}$. If, e.g., $\alpha=1$, i.e., there is complete knowledge spillover, LHS of (13) is positive (negative) considered in the benchmark model, an increase in union power decreases investment in innovation. 
for $a>(<)\left[1+d\left(1-F^{*}\right)\right]\left[1+2 d\left(1-F^{*}\right)\right]$, which implies like Proposition 3 that an increase in union power increases (decreases) innovation if the market is sufficiently large (small).

Following the same procedure, it can be shown that if there is no possibility of subcontracting, as considered in the benchmark model, an increase in union power decreases investment in innovation. In this situation, firm $M$ maximizes $\pi_{m}^{*}-C(F)=\frac{(2-\beta)^{2}(a-d(1-F))^{2}}{16}-\frac{F^{2}}{2}$ to determine the R\&D investment. The equilibrium $\mathrm{R} \& \mathrm{D}$ investment is $F^{*}=\frac{(a-d) d(2-\beta)^{2}}{8-d^{2}(2-\beta)^{2}}$. We get that $\frac{\partial F^{*}}{\partial \beta}=\frac{-16(a-d) d(2-\beta)}{\left(8-d^{2}(2-\beta)^{2}\right)^{2}}<0$

Thus, we show that the results shown in the text regarding the relation between union power and innovation under a binary $R \& D$ investment decision remain under continuous $R \& D$ investments. In this respect, we consider an uncertain $R \& D$, where a higher $R \& D$ investment helps to increase the probability of success in $R \& D$, and a deterministic $R \& D$, where a higher R\&D investment helps to reduce the labour coefficient more. 


\section{References}

Acs, Z., Audretsch, D.B., 1987. Innovation in large and small firms. Economics Letters 23, 109-112.

Acs, Z., Audretsch, D.B., 1988. Innovation in large and small firms: an empirical analysis. American Economic Review 78, 678-690.

Addison J.T., Hirsch, B.T., 1989. Union effects on productivity, profits, and growth: has the long run arrived? Journal of Labor Economics 7, 72-105.

Addison, J.T., Schnabel, C., Wagner, J., 2001. Works councils in Germany: their effects on establishment performance. Oxford Economic Papers 53, 659-694.

Addison, J.T., Wagner, J., 1994. UK unionism and innovative activity: some cautionary remarks on the basis of a simple cross-country test. British Journal of Industrial Relations 32, 83-98.

Agenor, P., 1996. The labour market and economic adjustment. IMF Staff Papers 32, 261335.

Audretsch, D.B., Graf v. d. Schulenburg, J.-M., 1990. Union participation, innovation, and concentration: results from a simultaneous model. Journal of Institutional and Theoretical Economics 146, 298-313.

Bas, M., Carluccio, J., 2009. Wage bargaining and the boundaries of the multinational firm. CEPR Discussion Paper, No. 7867.

Basole, A., Basu, D., Bhattacharya, R., 2014. Determinants and impact of subcontracting: Evidence from India's manufacturing sector. Working Paper 2014-04, Department of Economics, University of Massachusetts Amherst.

Beladi, H., Mukherjee, A., 2012. Market structure and strategic bi-sourcing. Journal of Economic Behavior \& Organization 82, 210-219. 
Beladi, H., Mukherjee, A., 2015. Union bargaining power and innovation in the presence of subcontracting. Working paper, No. 0012ECO-414-2015 (http://business.utsa.edu/wps/index.aspx\#eco), College of Business, University of Texas at San Antonio.

Betcherman G., 1991. The effects of unions on the innovative behaviour of firms in Canada. Industrial Relations Journal 22, 142-151.

Blalock, G., Gertler, G., 2008. Welfare gains from foreign direct investment through technology transfer to local suppliers. Journal of International Economics 74, 402421.

Boone, J., 2000. Technological progress, downsizing and unemployment. Economic Journal 110, 581-600.

Bowley, A.L., 1924. The mathematical groundwork of economics. Oxford University Press, Oxford.

Bronas, S.G., Deere, D.R., 1993. Unionisation, incomplete contracting, and capital Investment. Journal of Business 66, 117-132.

Chu, A.C., Cozzi, G., Furukawa, Y., 2016. Unions, innovation and cross-country wage inequality. Journal of Economic Dynamics and Control 64, 104-118.

Cohen, L., Young, A., 2006. Multisourcing: moving beyond outsourcing to achieve growth and agility. Harvard Business School Press, Boston, MA.

Connolly, R.A., Hirsch, B.T., Hirschey, M., 1986. Union rent seeking, intangible capital, and market value of the firm. Review of Economics and Statistics 68, 567-577.

Creane, A., Davidson, C., 2004. Multidivisional firms, internal competition, and the merger paradox. Canadian Journal of Economics 37, 951-977.

Du, J., Lu, Y., Tao, Z., 2006. Why do firms conduct bi-sourcing? Economics Letters 92, $245-249$. 
Du, J., Lu Y., Tao, Z., 2009. Bi-sourcing in the global economy. Journal of International Economics 77, 215-222.

Emons, W., 1996. Good times, bad times, and vertical upstream integration. International Journal of Industrial Organization 14, 465-484.

Freeman, R., Medoff, J., 1984. What do unions do? Basic Books, New York.

Guha-Khasnobis, B., Kanbur, R., 2006. Informal labour markets and development. McMillan-Palgrave, UK.

Grout, P.A., 1984. Investment and wages in the absence of binding contracts: a Nash bargaining approach. Econometrica 52, 449-460.

He, D., Nickerson, J., 2006. Why do firms make and buy? Efficiency, appropriability, and competition in the trucking industry. Strategic Organization 4, 43-69.

Hirsch, B.J., 1992. Firm investment behavior and collective bargaining strategy. Industrial Relations 31, 95-121.

Hirsch, B.T., Link, A.N., 1987. Labor union effects on innovative activity. Journal of Labor Research 8, 323-332.

Hobday, M., 1995. Innovation in East Asia: the Challenge to Japan. Edward Elgar, London.

Hou, C.M., Gee, S., 1993. National systems supporting technical advance in industry: the case of Taiwan. In: Nelson, R.R. (Ed.), National Innovation Systems: A Comparative Analysis. Oxford University Press, New York, pp. 384-413.

Javorcik, B.S., 2004. Does foreign direct investment increase the productivity of domestic firms? In search of spillovers through backward linkages. American Economic Review 94, 605-627.

Imai, K., 1992. The Japanese pattern of innovation and its evolution. In: Rosenberg, N., Laudan, R., Mowery, D. (Eds.), Technology and the Wealth of Nations. Stanford University Press, Stanford. 
Kotwal, A., Ramaswami, B., Wadhwa, W., 2011. Economic liberalization and Indian economic growth: what's the evidence? Journal of Economic Literature 49, 11521199.

Layard, R., Nickell, S., Jackman, R., 1991. Unemployment, macroeconomic performance and the labour market. Oxford University Press, Oxford.

Leahy, D., Montagna, C., 2000. Unionisation and foreign direct investment: challenging conventional wisdom? Economic Journal 110, C80-C92.

Lommerud, K.E., Meland, F., Sørgard, L., 2003. Unionised oligopoly, trade liberalisation and location choice. Economic Journal 113, 782-800.

Machin, S., Wadhwani, S., 1991. The effects of unions on investment and innovation: evidence from WIRS. Economic Journal 101, 324-330.

Maiti, D., Marjit, S., 2008. Trade liberalization, production organization and informal sector in the developing countries. The Journal of International Trade and Economic Development 17, 445-453.

Maiti, D., Marjit, S., 2009. Informal wage and formal sector productivity: theory and evidences from India. Working Paper Series No. E/301/2009, Institute of Economic Growth.

Maiti, D., Mukherjee, A., 2013. Trade cost reduction, subcontracting and unionised wage. Labour Economics 21, 103-110.

Mansfield, E., 1988. Industrial R\&D in Japan and the United States: a comparative study. American Economic Review 78, 223-228.

Marjit, S., 2003. Economic reform and informal wage - a general equilibrium analysis. Journal of Development Economics 72, 371-378.

Marjit, S., Ghosh, S., Biswas, A., 2007. Informality, corruption and trade reform. European Journal of Political Economy 23, 777-789. 
Mehrotra, S., Biggeri, M., 2007. Asian informal workers. Rutledge Taylor and Francis Group, New York.

Menezes-Filho, N., Van Reenen, J., 2003. Unions and innovation: a survey of the theory and empirical evidence. CEPR Discussion Paper, No. 3792.

Menezes-Filho, N., Ulph, D., Van Reenen, J., 1998. The determination of R\&D: empirical evidence on the rule of unions. European Economic Review 42, 919-930.

Moreno-Monroy, A.I., Pieters, J., Erumban, A.A., 2014. Formal sector subcontracting and informal sector employment in Indian manufacturing. IZA Journal of Labor \& Development 3, 1-17.

Mukherjee, A., 2008. Unionised labour market and strategic production decision of a multinational. Economic Journal 118, 1621-1639.

Mukherjee, A., Suetrong, K., 2012. Unionisation structure and outward foreign direct investment. Journal of Institutional and Theoretical Economics 168, 266-279.

Mukim, M., 2011. Industry and the urge to cluster: a study on the informal sector in India. SERC Discussion Paper 72, Department of International Development, London School of Economics.

Nickerson, J., Silverman, B., 2003. Why aren't all truckers drivers owner-operators? Asset ownership in interstate for-hire trucking. Journal of Economics and Management Strategy $12,91-118$.

Pack, H., Saggi, K., 2001. Vertical technology transfer via international outsourcing. Journal of Development Economics 65, 389-415.

Palokangas, T., 1996. Endogenous growth and collective bargaining. Journal of Economic Dynamics and Control 20, 925-944.

Palokangas, T., 2004. Union-firm bargaining, productivity improvement and endogenous growth. Labour 18, 191-205. 
Pavitt, K., Robson, M., Townsend, J., 1987. The size distribution of innovating firms in the UK: 1945-1983. Journal of Industrial Economics 35, 297-316.

Puranam, P., Gulati, R., Bhattacharya, S., 2013. How much to make and how much to buy: explaining plural sourcing strategies. Strategic Management Journal 34, 1145-1161.

Ramaswamy, K.V., 1999. The search for flexibility in Indian manufacturing: new evidence on subcontracting activities. Economic and Political Weekly 34, 363-368.

Saha, B., Sen, K., Maiti, D., 2013. Trade openness, labour institutions and flexibilisation: theory and evidence from India. Labour Economics 24, 180-195.

Sahu, P.P., 2010. Subcontracting in India's unorganised manufacturing sector: a mode of adoption or exploitation? Journal of South Asian Development 5, 53-83.

Schnabel, C., Wagner, J., 1992. Unions and innovative activity in Germany. Journal of Labor Research 8, 393-406.

Schnabel, C., Wagner, J., 1994. Industrial relations and trade union effects on innovation in Germany. Labour 8, 489-504.

Schneider, F., Enste, D., 2000. Shadow economies: size, causes and consequences. Journal of Economic Literature 38, 77-114.

Shubik, M., Levitan, R., 1980. Market structure and behaviour. Harvard University Press, Cambridge, MA.

Shy, O., Stenbacka, R., 2005. Partial outsourcing, monitoring cost, and market structure. Canadian Journal of Economics 38, 1173-1190.

Stenbacka, R., Tombak, M., 2012. Make and buy: balancing bargaining power. Journal of Economic Behavior \& Organization 81, 391-402.

Ulph, A., Ulph, D., 1989. Labour markets and innovation. Journal of Japanese and International Economics 3, 403-423. 
Ulph, A.M., Ulph, D.T., 1994. Labour markets and innovation: ex-post bargaining. European Economic Review 38, 195-210.

Ulph, A.M., Ulph, D.T., 1998. Labour markets, bargaining and innovation. European Economic Review 42, 931-939.

Ulyssea, G., 2010. Regulation of entry, labour market institutions and the informal sector. Journal of Development Economics 91, 87-99.

UNIDO, 1999. Technology transfer in subcontracting. US/GLO/94/009, United Nations Industrial Development Organization.

Wattanapruttipaisan, T., 2002. SME subcontracting as bridgehead to competitiveness: framework for an assessment of supply-side capabilities and demand-side requirements. Asia-Pacific Development Journal 9, 65-87.

WTO-ILO, 2009. Globalization and informal jobs in developing countries. World Trade Organization and International Labour Office, Geneva. 